\title{
Hybridization of Deoxyribonucleotide Sequences of Yersinia enterocolitica and Other Selected Members of Enterobacteriaceae ${ }^{1}$
}

\begin{abstract}
R. L. MOORE AND R. R. BRUBAKER
Division of Pathology, Faculty of Medicine, The University of Calgary, Calgary, Alberta, Canada, and Department of Microbiology and Public Health, Michigan State University, East Lansing, Michigan 48824

Using Yersinia enterocolitica Becht 18 as a standard reference, we obtained deoxyribonucleic acid base sequence homologies ranging from 79 to $100 \%$ for 11 additional isolates of the species representing 9 serotypes. These organisms, many of which exhibited dissimilar biochemical reactions, therefore belong to one and the same species. However, the degree of relatedness between $Y$. enterocolitica and the established members of the genus (Yersinia pestis and Yesinia pseudotuberculosis) was low (18 to 24\%), approaching that obtained for some of 10 selected isolates of 7 other genera of Enterobacteriaceae (2 to 16\%). These findings suggest that the proposal to include $Y$. enterocolitica within the genus Yersinia requires further evaluation.
\end{abstract}

The name Bacterium enterocoliticum was used by Schleifstein and Coleman (25) to refer to organisms that resembled Yersinia pseudotuberculosis (Pasteurella pseudotuberculosis) with respect to biochemical properties and pathology of disease in humans. Similar bacteria were subsequently described under a variety of designations, the most common being Pasteurella pseudotuberculosis $\mathrm{b}, P$. pseudotuberculosis-like species, Pasteurella Y, and Pasteurella $X(1,2,6,7,10)$. Although it was soon evident that these isolates did not belong to $Y$. pseudotuberculosis $(6,12-14)$, their superficial similarity to the latter prompted Frederiksen (9) to propose that they be referred to by the name Yersinia enterocolitica. The validity of this proposal, however, was questioned on the grounds that much diversity existed between strains of this newly described entity $(15,16)$. For example, certain isolates produced indole and fermented sugars (xylose, aesculin, and salicin), whereas others did not. These and other biochemical tests enabled Niléhn (22) and Wauters (Ph.D. thesis, Univ. of Vonder, Louvain, Belgium, 1970) to separate the organisms into five biotypes. Only strains of biotype 5, which differ markedly from the strains of the other biotypes, clustered separately in the similarity matrix constructed by Stevens and Mair (26). In a similar comparison with other members of Enterobacteriaceae, $Y$. enterocolitica was also resolved in an independent group (11).

To provide further information regarding the taxonomic position of $Y$. enterocolitica, we have compared the homology of polynucleotide se-

' Article no. 7200 of the Michigan Agricultural Experiment Station. quences of deoxyribonucleic acid (DNA) prepared from standard reference and from atypical strains. In a similar study, the relationship between $Y$. enterocolitica and some selected members of Enterobacteriaceae was investigated.

\section{MATERIALS AND METHODS}

Bacteria. All of the strains of $Y$. enterocolitica used in this study were obtained through the courtesy of W. Knapp (Universität Erlangen-Nürnberg, Erlangen, W. Germany). The Pasteur Institute designations (Ye no.), synonyms, serotypes (29,30), and selected properties of these strains are shown in Table 1. The strains of $Y$. pseudotuberculosis and $Y$. pestis used were from the Michigan State University collection. The other organisms studied were obtained from the American Type Culture Collection (Rockville, Md.), the Foothills Hospital (Calgary, Alberta), or the Provincial Laboratories (Edmonton, Alberta).

Media and cultivation. All cultures were aerated in $3 \%$ Trypticase soy broth with $0.1 \%$ yeast extract. $Y$. pestis and Erwinia carotovora cultures were grown at $30 \mathrm{C}$, and the remaining organisms were grown at $37 \mathrm{C}$.

Preparation of DNA. Purified DNA, prepared by the method of Marmur (19), was sheared by passage through a French pressure cell at $15,000 \mathrm{lb} / \mathrm{in}^{2}$ to yield a molecular weight of approximately 300,000 . This preparation was then dialyzed against three changes of distilled water and three changes of $0.1 \mathrm{M}$ $\mathrm{NaCl}$ as outlined by Crosa et al. (5). Tritium-labeled DNA was prepared similarly from cells grown in the presence of $\left[8{ }^{3} \mathrm{H}\right]$ adenine $(27 \mathrm{Ci} / \mathrm{mM}$, Amersham/Searle, Toronto, Ontario) and then further purified by chromatography on calcium hydroxyapatite (Bio-Rad Laboratories, Richmond, Calif.) and dialysis against three changes of $0.1 \mathrm{M} \mathrm{NaCl}$.

DNA base composition. The base compositions of 
TABLE 1. Strains of Yersinia enterocolitica used in this investigation

\begin{tabular}{|c|c|c|c|c|c|c|c|c|}
\hline \multirow{2}{*}{ Ye no. } & \multirow{2}{*}{$\begin{array}{l}\text { Additional strain } \\
\text { designations }\end{array}$} & \multirow{2}{*}{$\begin{array}{l}\text { Sero- } \\
\text { group }^{a}\end{array}$} & \multicolumn{5}{|c|}{ Biochemical characteristics $^{b}$} & \multirow{2}{*}{$\begin{array}{c}\text { Mol\% } \\
\text { G+C } \\
\text { content of } \\
\text { DNA }\end{array}$} \\
\hline & & & Indole & Xylose & Aesculin & Salicin & $\begin{array}{c}\text { Gas } \\
\text { (glucose) }\end{array}$ & \\
\hline 62 & Becht $18 \mathrm{C}^{d}$ & 1 & 0 & - & 0 & 0 & 0 & 47.6 \\
\hline 64 & Becht 51C & 1 & 0 & + & 0 & 0 & 0 & 47.2 \\
\hline 39 & Daniels $905^{d}$ & 2 & 0 & + & 0 & 0 & 0 & 47.6 \\
\hline 128 & Daniels 924 & 2 & 0 & - & 0 & 0 & 0 & 47.6 \\
\hline 75 & Dickinson $280 / 1$ & 3 & 0 & 0 & 0 & 0 & 0 & 48.5 \\
\hline 96 & Fredericksen P76 & 4 & + & + & 0 & 0 & 0 & 47.3 \\
\hline 91 & Fredericksen P71 & 4 & 0 & - & 0 & 0 & 0 & 47.0 \\
\hline 124 & Jument & $5 A$ & + & - & + & + & + & 47.3 \\
\hline 102 & Bojoson-Møller $70^{e}$ & 6 & + & + & + & + & + & 47.6 \\
\hline 106 & Borg-Petersen P413 & 7 & + & + & + & + & + & 48.2 \\
\hline 161 & Schleifstein 33114 & 8 & + & + & 0 & 0 & 0 & 47.7 \\
\hline 373 & Ahvonen $246 / 68^{d}$ & 9 & + & + & 0 & 0 & 0 & 48.3 \\
\hline
\end{tabular}

${ }^{a}$ According to Wauters (Ph.D. thesis) or Winblad (30).

${ }^{b}$ According to Knapp and Thal (15); +, positive; 0, negative; -, not reported.

$r \mathrm{G}+\mathrm{C}$, Guanine plus cytosine. Determined in this investigation.

${ }^{d}$ Standard reference strains (27).

- Synonymous with Fredericksen P 219.

the various preparations of DNA were determined on a Gilford $2400-S$ spectrophotometer by the thermal denaturation method of Mandel and Marmur (18).

DNA reassociation. Heat-disassociated DNA $(150 \mu \mathrm{g})$ from the various bacterial strains was added to radioactive DNA $(0.1 \mu \mathrm{g})$ from $Y$. enterocolitica Becht 18, Y. pseudotuberculosis PB1/t, or Escherichia coli B in $1 \mathrm{ml}$ of $0.17 \mathrm{M} \mathrm{NaCl}$. Nearoptimal conditions for reassociation were obtained by incubating this mixture for $16 \mathrm{~h}$ at $64 \mathrm{C}$, a temperature which, at this concentration of salt, is about $25 \mathrm{C}$ below the thermal denaturation of the DNA. Unpaired DNA fragments remaining after incubation were then hydrolyzed with $\mathrm{S} 1$ endonuclease (28). The enzyme mixture was prepared by adding 0.2 volume of standard enzyme preparation to 2.0 volume of heat-disassociated (Calbiochem) salmon DNA $(200 \mu \mathrm{g} / \mathrm{ml})$ and 8 volumes of a solution composed of $400 \mathrm{ml}$ of $0.5 \mathrm{mM} \mathrm{ZnSO}_{4}, 400 \mathrm{ml}$ of $0.15 \mathrm{M}$ sodium acetate ( $\mathrm{pH} 4.5$ ), and $8.77 \mathrm{~g}$ of $\mathrm{NaCl}$ (5). Each sample received $1 \mathrm{ml}$ of enzyme mixture and was then incubated at $50 \mathrm{C}$ for $20 \mathrm{~min}$. The samples were then precipitated with $0.25 \mathrm{ml}$ of $50 \%$ trichloroacetic acid, filtered, and dried, and their radioactivity was measured in toluene liquid scintillation fluid in a Beckman LS-330 scintillation counter. In the absence of the $150 \mu \mathrm{g}$ of nonlabeled DNA, no effect on double-stranded DNA was observed in assays carried out under these conditions while $97 \%$ of singlestranded DNA underwent hydrolysis. DNA homology values are expressed as the percentage of tritiated DNA complexed with heterologous DNA compared with that complexed with the homologous DNA (100\%).

\section{RESULTS AND DISCUSSION}

DNA base composition. The DNA base compositions of the various strains of $Y$. enterocolit- ica ranged from 47.0 to $48.5 \mathrm{~mol} \%$ guanine plus cytosine (Table 1). These values were higher than the approximate $45 \mathrm{~mol} \%$ guanine plus cytosine content reported for $Y$. enterocolitica by Domaradskij et al. (8) and exceeded the 46 to 47 mol\% guanine plus cytosine content obtained for $Y$. pseudotuberculosis and $Y$. pestis $(17,20,24)$. The average observed for $Y$. enterocolitica was significantly greater than the 36 to $43 \mathrm{~mol} \%$ guanine plus cytosine content reported for members of the genus Pasteurella (Bergey's Manual, 8th ed.). No particular relationship between the base composition and the serotype of $Y$. enterocolitica was noted.

DNA base sequence homologies. Relatedness values among $Y$. enterocolitica ranged from 79 to $100 \%$ (Table 2). A narrow distribution of this nature, which is similar to that reported for a majority of $E$. coli isolates (4), indicates that all of the tested strains of $Y$. enterocolitica are of the same species. DNA preparations from strains of serogroups 1, 2, and 3 (29) were essentially homologous.

Very low base sequence homology (20 to $23 \%$ ) was observed between reference DNA of $Y$. enterocolitica and that of single strains of the established members of the genus ( $Y$. pestis and $Y$. pseudotuberculosis). However, the latter exhibited a high degree of homology (83\%) similar to the value reported previously by Ritter and Gerloff (23). As expected, essentially no homology was observed between reference DNA of $Y$. enterocolitica and a selected representative of the genus Pasteurella ( $P$. multocida).

The low homology values found between 
TABLE 2. DNA homology values determined between Yersinia enterocolitica, Yersinia pseudotuberculosis, Escherichia coli, and other selected bacteria

\begin{tabular}{|c|c|c|c|c|}
\hline \multirow[b]{2}{*}{ Organism } & \multirow[b]{2}{*}{ Strain designation } & \multicolumn{3}{|c|}{ DNA homology ${ }^{a}$} \\
\hline & & $\begin{array}{c}\text { Yersinia } \\
\text { enterocolitica } \\
\text { Ye } 62\end{array}$ & $\begin{array}{c}\text { Yersinia } \\
\text { pseudo- } \\
\text { tuberculosis } \\
\text { PBI }+\end{array}$ & $\begin{array}{c}\text { Escherichia } \\
\text { coli B }\end{array}$ \\
\hline \multirow[t]{12}{*}{ Yersinia enterocolitica } & Ye 62 & $(100)$ & 20 & 11 \\
\hline & Ye 64 & 103 & $-b$ & - \\
\hline & Ye 39 & 100 & 20 & - \\
\hline & Ye 128 & 102 & 21 & - \\
\hline & Ye 75 & 99 & 23 & - \\
\hline & Ye 96 & 80 & 24 & - \\
\hline & Ye 91 & 90 & - & - \\
\hline & Ye 124 & 83 & 22 & - \\
\hline & Ye 102 & 79 & - & - \\
\hline & Ye 106 & 81 & 18 & - \\
\hline & Ye 161 & 81 & - & - \\
\hline & Ye 373 & 89 & 20 & - \\
\hline Yersinia pseudotuberculosis & $\mathrm{PB} 1 /+$ & 22 & $(100)$ & 9 \\
\hline Yersinia pestis & EV 76 & 23 & 83 & 9 \\
\hline Escherichia coli & $\mathrm{B}$ & 13 & 9 & $(100)$ \\
\hline Serratia marcescens & $\mathrm{ES}$ & 16 & 11 & 14 \\
\hline Shigella dysenteriae & ATCC 13313 & 12 & 3 & 83 \\
\hline Salmonella typhimurium & LT-2 & 11 & 3 & 26 \\
\hline Klebsiella pneumoniae & $298 / 53$ & 9 & 8 & - \\
\hline Erwinia carotovora & ATCC 495 & 9 & 3 & - \\
\hline Proteus morganii & 8169 & 8 & 4 & - \\
\hline Proteus rettgeri & ATCC 9918 & 4 & - & - \\
\hline Proteus vulgaris & ATCC 6380 & 3 & - & - \\
\hline Proteus mirabilis & D 799 & 2 & - & - \\
\hline Pasteurella multocida & ATCC 6524 & 0 & 1 & - \\
\hline Neisseria subflava & & 0.7 & 0.1 & - \\
\hline Bacillus subtilis & & 1 & 0 & $\longrightarrow$ \\
\hline
\end{tabular}

"The results given are the averages of three determinations corrected for background by subtracting the value obtained with T4 coliphage DNA (5 to $6 \%$ of the input labeled DNA). The degree of homologous binding was 80 to $89 \%$ of the input labeled DNA. DNA of Y. enterocolitica Ye 62, Y. pseudotuberculosis $\mathrm{PBV}+$, and $E$. coli B was $52,000,20,000$, and 20,000 counts $/$ min per $\mu \mathrm{g}$, respectively.

"Dash indicates value not determined.

DNA of $Y$. enterocolitica and that of other enteric organisms indicate that there is only a distant relationship between these species, although this relationship is of the same order as that encountered among many genera of the family Enterobacteriaceae $(3,21)$. Of the latter, DNA of Serratia marcescens exhibited the greatest homology with that of $Y$. enterocolitica.

The relatedness found between $E$. coli and $Y$. pestis was lower than the earlier published value of $22 \%$ (23) due to differences in the method and conditions of reassociation. The homology between $E$. coli and $Y$. enterocolitica was only slightly higher than that between $E$. coli and the established yersiniae. The extent of homology between DNA of $E$. coli and that of $S$. marcescens, Shigella dysenteriae, or Salmonella typhimurium was similar to values obtained previously $(3-5,21)$.

Together, these results support the hypothesis that the biochemically and serologically diverse strains currently grouped as $Y$. enterocolitica (9) constitute a valid species, at least with respect to biotypes 1 through 4 (22; Wauters, $\mathrm{Ph}$.D. thesis). This species, however, bears only a distant genetic relationship to the accepted members of the genus Yersinia, namely, $Y$. pestis and $Y$. pseudotuberculosis. The assumption that $Y$. enterocolitica was closely related to $Y$. pseudotuberculosis was evidently based on expression of common, but superficial, biochem- 
ical reactions, similar DNA base compositions, and ability to share the same environmental niche in nature.

\section{ACKNOWLEDGMENTS}

This research was supported by a grant to $R$. L. Moore from Foothills Hospital, Calgary, Alberta, Canada, and by Public Health Service grant AI-08468 to R. R. Brubaker from the National Institute of Allergy and Infectious Diseases.

The excellent technical assistance of Elizabeth Roberts and Emilia R. DeBlasio is gratefully acknowledged.

\section{REPRINT REQUESTS}

Address reprint requests to: Dr. Robert R. Brubaker Department of Microbiology and Public Health, Michigan State University, East Lansing, Mich. 48824.

\section{LITERATURE CITED}

1. Akkermans, J. P., and J. I. en Terpstra. 1963. Pseudotuberculose bij chinchilla's veroorzaakt door een bijzowdere species. Tijdschr. Diergeneeskd. 88:91-95.

2. Becht, H. 1962. Untersuchungen über die Pseudotuberkulose beim Chinchilla. Dtsch. Tieraertl. Wochenschr. 69:626-627.

3. Brenner, D. J., G. R. Fanning, K. E. Johnson, R. V. Citarella, and S. Falkow. 1969. Polynucleotide sequence relationships among members of Enterobacteriaceae. J. Bacteriol. 98:637-650.

4. Brenner, D. J., G. R. Fanning, F. J. Skerman, and S. Falkow. 1972. Polynucleotide sequence divergence among strains of Escherichia coli and closely related organisms. J. Bacteriol. 109:953-965.

5. Crosa, J. H., D. J. Brenner, and S. Falkow. 1973. Use of a single-strand specific nuclease for analysis of bacterial and plasmid deoxyribonucleic acid homo- and heteroduplexes. J. Bacteriol. 115:904-911.

6. Daniels, J. J. H. M. 1963. Untersuchungen an als Pasteurella pseudotuberculosis diagnostiziersten Stämmen von Chinchillas. Zentralbl. Veterinaermed. 10:413-417.

7. Dickinson, A. B., and G. Mocquot. 1961. Studies on the bacterial flora of the alimentary tract of pigs. I. Enterobacteriaceae and other gram-negative bacteria. J. Appl. Bacteriol. 324:252-284.

8. Domaradskij, I., V. Marchenkov, and N. Shimanjuk. 1973. New data obtained in comparative studies of plague agent and related organisms. Contrib. Microbiol. Immunol. 2:2-3.

9. Frederiksen, W. 1964. A study of some Yersinia pseudotuberculosis-like bacteria ("Bacterium enterocoliticum" and "Pasteurella X"), p. 103-104. In Proceedings of the 14th Scandinavian Congress of Pathology and Microbiology, Oslo.

10. Hässig, A., J. Karrer, and F. Pusterla. 1949. Ubër Pseudotuberkulose beim Menschen. Schweiz. Med. Wochenschr. 74:971-973.

11. Johnson, R., R. R. Colwell, R. Sakazaki, and K. Tamura. 1975. Numerical taxonomy study of Enterobacteriaceae. Int. J. Syst. Bacteriol. 25:12-37.

12. Knapp, W. 1954. Pasteurella pseudotuberculosis unter besonderer Berüchsichtigung ihrer humanmedizinischen Bedeutung. Ergeb. Mikrobiol. Immunitaetsforsch. Exp. 32:196-269.

13. Knapp, W., and E. Thal. 1963. Untersuchungen über die kulturell-biochemischen, serologischen, tierexperimentellen und immunologischen Eigenschaften ei- ner vorläufig "Pasteurella $X$ " benannten Bakterienart. Zentralbl. Bakteriol. Parasitenkd. Infektionskr. Hyg. Abt. 1 Orig. Reihe A 190:472-484.

14. Knapp, W., and E. Thal. 1965. Kurzmitteilung über kulturell-biochemische serologische und immunobiologische Untersuchungen mit einer vorläufig "Pasteurella $X$ " benannten Bakterienart. Kleinter-Prax. 10:88.

15. Knapp, W., and E. Thal. 1973. Differentiation of Yersinia enterocolitica by biochemical reactions. Contrib. Microbiol. Immunol. 2:10-16.

16. Knapp, W., and E. Thal. 1973. Die biochemische Charakterisierung von Yersinia enterocolitica (syn. "Pasteurella $X$ ") als Grundlage eines vereinfachten $\mathrm{O}$ Antigen-schemas. Zentralbl. Bakteriol. Parasitenkd. Infektionskr. Hyg. Abt. 1 Orig. Reihe A 223:88-105.

17. Lawton, W. D., B. C. Morris, and T. W. Burrows. 1968. Gene transfer in strains of Pasteurella pseudotuberculosis. J. Gen. Microbiol. 52:25-34.

18. Mandel, M., and J. Marmur. 1968. Use of ultraviolet absorbance-temperature profile for determining the guanine plus cytosine content of DNA, p. 195-206. In L. Grossman and K. Moldave (ed.), Methods in enzymology, vol. 12B. Academic Press Inc., New York.

19. Marmur, J. 1961. A procedure for the isolation of deoxyribonucleic acid from micro-organisms. J. Mol. Biol. 3:208-218.

20. Marmur, J., and P. Doty. 1962. Determination of the base composition of deoxyribonucleic acid from its thermal denaturation temperature. J. Mol. Biol 5:109-118.

21. Moore, R. L., and B. J. McCarthy. 1967. Comparative study of ribosomal ribonucleic acid cistrons in enterobacteria and myxobacteria. J. Bacteriol. 94:10661074.

22. Niléhn, B. 1969. Studies on Yersinia enterocolitica. Acta Pathol. Microbiol. Scand. 206(Suppl.):1-48.

23. Ritter, D. B., and R. K. Gerloff. 1966. Deoxyribonucleic acid hybridization among some species of the genus Pasteurella. J. Bacteriol. 92:1838-1939.

24. Schildkraut, C. L., J. Marmur, and P. Doty. 1962. Determination of the base composition of deoxyribonucleic acid from its buoyant density in $\mathrm{CsCl}$. J. Mol. Biol $4: 430-443$.

25. Schleifstein, J., and M. B. Coleman. 1939. An unidentified microorganism resembling $B$. lignieri and Pasteurella pseudotuberculosis, and pathogenic for man N.Y. State J. Med. 30:1749-1753.

26. Stevens, S., and N. S. Mair. 1973. A numerical taxonomic study of Yersinia enterocolitica strains. Contrib. Microbiol. Immunol. 2:17-22.

27. Subcommittee on Pasteurella, Yersinia, and Francisella. 1971. Report (1966-1970) of the Subcommittee on Pasteurella, Yersinia, and Francisella to the International Committee on Nomenclature of Bacteria. Int. J. Syst. Bacteriol. 21:157.

28. Sutton, W. D. 1971. A crude nuclease preparation suitable for use in DNA reassociation experiments. Biochim. Biophys. Acta 240:522-531.

29. Wauters, G., L. LeMinor, and M. Chalon. Antigènes somatiques et flagellaires des Yersinia enterocolitica. Ann. Inst. Pasteur Paris 120: 631-642.

30. Winblad, S. 1967. Studies on serological typing of Yersinia enterocolitica. Acta Pathol. Microbiol. Scand. 187(Suppl.):115.

31. Winblad, S. 1968. Studies on O-antigen factors of Yersinia enterocolitica. Progr. Immunobiol. Stand. 9:337342. 